\title{
Mathematical Literacy as a school subject: Failing the progressive vision?
}

\author{
Iben Maj Christiansen \\ School of Education and Development, Faculty of Education, University of KwaZulu-Natal \\ christianseni@ukzn.ac.za
}

The National Curriculum Statement (NCS) for Mathematical Literacy (ML) is part of a progressive agenda for increased democracy and social justice. It claims that the new school subject Mathematical Literacy will provide learners with awareness and understanding of the role that mathematics plays in the modern world. However, the analysis developed in this paper indicates that the superficial engagement with complex applications of mathematics implied by the ML NCS is not likely to live up to its claim. In addition, we do not understand enough about the connections between mathematical, technological and reflective knowledge/knowing/competencies to know how to facilitate the awareness and understanding that is part of the vision of the ML NCS.

\section{Introduction}

Internationally, 'mathematical literacy' refers to the competence of individuals. Some writers see mathematical literacy as a narrowly defined competence, which can be demonstrated on word problems or even 'pure' calculations (Bynner and Parsons, 1997; Basic Skills Agency, 1997). At the other end of the spectrum we see strong links to a critical or democratic competence (Frankenstein, 1990; Skovsmose, 1994; Christiansen, 1996b; Vithal, 2003; Kibi, 1993; Povey, 2003). ${ }^{1}$ One aspect thereof is using mathematics as a tool in gaining insights into oppression, inequalities, and exploitation (see in particular Mellin-Olsen, 1987; Frankenstein, 1981; Fasheh, 1996)), another is to become aware of the effects of applying mathematical models in society (Niss, 1984; BooßBavnbek and Pate, 1989; Niss, 1990; Blomhøj, 1999; Skovsmose, 1994; Christiansen, 2000; Blum and Niss, 1989), and a third component has to do with mathematics as a 'gate keeper', i.e., access to further education, discourses of power, etc. (Povey, 2003; Jungwirth, 2003).

In South Africa, 'mathematical literacy' (ML) also refers to a school subject, about to be implemented. The ML curriculum justifies itself in two ways; one is through claims of utility, the other is through claims that it will "provide learners with awareness and understanding of the role that mathematics plays in the modern world" (Department of Education, 2003). Elsewhere, I have interrogated the first justification

\footnotetext{
${ }^{1}$ For an overview and discussion of different views on mathematical literacy, see Jablonka (2003).
}

(Christiansen, 2007). In this paper, I interrogate the second one.

The ML NCS adheres to a proclaimed progressiveness in stating that it is part of a larger agenda for improvement of living conditions, social justice and democracy (chapter 1, general to all the NCSs). In specific reference to critical citizenry:

To be a participating citizen in a developing democracy, it is essential that the adolescent and adult have acquired a critical stance with regard to mathematical arguments presented in the media and other platforms. The concerned citizen needs to be aware that statistics can often be used to support opposing arguments, for example, for or against the use of an ecologically sensitive stretch of land for mining purposes. In the information age, the power of numbers and mathematical ways of thinking often shape policy. Unless citizens appreciate this, they will not be in a position to use their vote appropriately. (Department of Education, 2003)

In this paper, I set out to investigate the claim of the ML NCS that it provides learners with awareness and understanding of the role of mathematics in the modern world. This gives rise to three questions, namely:

(1) What do we know about the role of mathematics in 'the modern world'? And does the NCS for ML reflect this?

(2) What do we know about learners becoming aware of this role?

Pythagoras 64, December, 2006, pp. 6-13 
(3) What are the issues of a curriculum serving this purpose?

I will address the two first questions in turn, but for the sake of brevity only raise some concerns relating to the third question.

\section{The role of mathematics in society}

The National Curriculum Statement for Mathematical Literacy writes about the role played by mathematics as if it can be assumed that this role is well known, not the least to the educators. But what do we know about this role? Some general philosophical considerations have been given to it, but the literature still only contains sketches of an understanding.

We know that mathematics can be a powerful modelling tool. It is in modelling complex phenomena that mathematics assists us in developing insights we otherwise could not have had. Some of the examples listed in the NCS belong in this category. For instance, a 'dialogue' between medical sciences (including community health science) and mathematics can lead to the development of a model for AIDS. Complex mathematical models, based on natural geography and geo-physics, have been developed for the interplay between our impact on the environment, global warming and the depletion of the ozone layer. Statistical models can be used to indicate the extent to which two factors can be said to be correlated.

On the other hand, this also means that mathematics can change the discourses around these issues. Because the models are not transparent to most people, they dramatically change the discourse surrounding these issues:

The modelling process could create a specific way of interpreting the problem; it could cause a limitation on the group of people who have the possibility of participating in the discussion of problem-solving, and, as a consequence of a rationalistic and calculatoric [sic] way of arguing, a specific type of solution could become created. (Skovsmose, 1990: 776)

The prestige of mathematics can emerge from theories which formulate results and connections in the language of mathematics, and thus provide these with a (false) sense of objectivity.

On the other hand, those norms to which mathematics is contributed can reduce the importance of theories which cannot be formulated in a strict mathematical language. (Skovsmose, 1984: 41-44, my translation)

This of course rests on the false acceptance of an expert-ideology (Kemp, 1980). The ways in which mathematics together with the expert ideology transforms language games have been demonstrated elsewhere (Christiansen, 1996a; 1997). In relation to models of the depletion of the ozone layer, I found that:

Because models are used as arguments, they can be challenged, and this creates the possibility of shifting the attention from what is predicted to how the prediction was obtained. Thus, the debate about which course of actions to take can be substituted by a debate about the certainty of predictions, the quality of the model, and the limits to the underlying theory and assumptions. This is one way in which the original problem and the form of argumentation could be altered, transformed into something else.

As mentioned earlier the introduction of quantitative arguments could alter the perception of the original problem - how to act in response to the ozone depletion - in other ways. Quantitative arguments are an integral part of hypothetical reasoning creating scenarios which can indicate the graveness of the problem. But the possibility of choosing between scenarios can also transform the problem towards a discussion of how much CFC can be emitted. The models become tools in operating closer to critical points. (1996a: 69).

I refer to this transformation of a fundamentally political problem into a question which can be addressed through technical means as the technocratic transformation (Christiansen, 1996a). It was also evident in other examples.

Perhaps it is these roles of mathematics to which the NCS refers, when it states that "Mathematical Literacy provides learners with an awareness and understanding of the role that mathematics plays in the modern world"? If so, we are lacking analyses of the ways in which mathematics influences decisions and political debates in South Africa. It may be that the expert ideology is less prevalent here than in the European countries from which the philosophical considerations above arise. Paola Valero (1999) makes this point in relation to Latin America: 
[...] decisions are made based [...] also on personal loyalty [...], political convenience, power of conviction through the use of language or violent, physical imposition. In this political scenario and 'rationality', mathematics does not necessarily constitute a formatting power that greatly influences decision making. (Valero, 1999)

However, let me, for the purpose of this paper, assume that mathematics does indeed play the same role in South Africa as in Denmark, where the analyses of Skovsmose and myself originate. Paradoxically, some of the examples given in the NCS refer to fairly advanced mathematical models, but the learners are not expected to engage with the models on a level which would lead to substantial insights - neither in the phenomena modelled nor in the technocratic transformations and other alterations of discourses generated through the use of mathematics and science. For instance, learners should be able to

interpret graphs of temperature against time of day during winter over a number of years to investigate claims of global warming (Department of Education, 2003)

Anyone who has engaged with issues of global warming knows that it requires substantial engagement with various issues to even begin to investigate claims of global warming. For instance, the increased urbanisation has meant that places which 100 years ago where fairly rural are now highly urbanised which does increase the temperature enough to blur any trends due to global warming. More importantly, the complex nature of the interplay between atmosphere and surface environment means that global warming may make certain areas warmer and others colder. A complex mathematical model based on a deep understanding of natural geography, physics, etc. can assist our understanding of this complex phenomenon. But this is disguised by the simple level of engagement which is expected from the ML learners. Thus, it serves nothing in terms of engaging with global warming or becoming aware of the real uses of mathematics as a modelling tool; it is simply an exercise in reading graphs, in the disguise of global warming issues. In this respect, it is not inviting insights into the complex role and function of mathematics in society. ${ }^{2}$

\footnotetext{
2 In addition, it assumes little of South African ML learners' ability to engage deeply with relevant issues. In that way, it is bound to construct the learners opting for ML as the less able. By referring to ability as constructed, I do not mean to imply that all learners can do
}

In all fairness, I should mention that there are a few positive exceptions where the learners are directed to engage with the extent to which the models can say something about the underlying cause and effect, as in

- Does a positive correlation between Mathematics marks and Music marks necessarily mean that facility in Mathematics is dependent on musical aptitude? (Assessment Criteria 12.4.2)

- Does a positive correlation between pollution levels and TB infections necessarily mean that pollution causes TB? (12.4.2)

But perhaps the NCS is more directed towards using mathematics as a tool to obtain insights into society? However, given the transformative agenda of the NCSs, so strongly emphasised in the general chapter 1 , what is striking is the nature of most of the examples chosen. Many are concerned with investments, profit margins, number of employees, choosing best car hire or cell phone purchase, but also include investments in different currencies, installing an imported washing machine, tracking weight loss, etc. There is no encouragement to compare incomes and benefits, living conditions, access, effect of education on future income levels, etc. In other words, the curriculum appears to be directed at creating educated consumers in a capitalist economy, which remains unchallenged; there are few attempts at directing teachers' and learners' attention to truly transformative issues. When the NCS states that the aim is to "heal the divisions of the past and establish a society based on democratic values, social justice and fundamental human rights", it does so without explicitly challenging the divisions created by capitalism or the artificial hierarchy of knowledge resulting in the theory/practice division. In addition, there is no exploration of the reproduction of capital and its human consequences. And so the NCS reflects an adherence to status quo and thus a contradiction of its proclaimed aims (cf. also Dowling, 1998: 19). It is thus set on a path of contributing to the reproduction of social inequalities. In that sense, the NCS fails to engage mathematics to obtain

the same; when they enter grade 10; cultural capital is very much at play (Bourdieu, 1983/2004). I am simply referring to the continuous construction and reconstruction of learners' ability as a complex of 'expected' behaviours, 'needs', etc. (Dowling, 1998). Thus, it should also be clear that I am not simply referring to the construction of learners opting for ML as the less able in terms of not being 'able' to complete the Mathematics course for grades 10-12, but as a broader set of expectations about learners' ability to engage critically and analytically with any type of issue. 
insights into society in general, not simply into the role of mathematics in society.

\section{Facilitating learners' awareness of the role of mathematics in society}

The NCS for ML is, naturally for an outcomesbased curriculum, mostly concerned with the competencies which learners should be able to demonstrate at the end of their education. There is mention of what learners should or could engage with to become more aware of the role of mathematics in society. All fourteen of these examples (excerpts of the 57 outcomes statements and assessment criteria) are about critical investigation or discussion of the use of mathematics. For instance:

- Critical awareness of how data can be manipulated to prove opposing views should be developed (Chapter 2, Outcome 4)

- criticise numerically-based arguments (10.1.1)

- ... linking the discussion to the way Mathematics [sic!] can be used to argue opposing points of view (12.1.3)

- Critically interpret tables and graphs that relate to a variety of real-life situations (10.2.3)

- identify possible sources of bias in gathering the data (11.4.3)

Working with such examples could facilitate learners' insights in some of the ways in which mathematics is used in society, and thus ultimately in the function of society itself. Such examples could have the potential to address the ways in which mathematics may alter discourses, etc. However, it is also possible to meet these outcomes or assessment criteria with rather simple examples, without the potential to engage the complex issues discussed in the previous section. Furthermore, even if the 'right' examples are chosen, will engaging with them necessary lead to exemplary insight into the use of mathematics in society?

There is an existing body of research in mathematics education which addresses how learners can learn mathematical modelling and thereby experience the power of mathematics in addressing complex issues (see for instance the ICTMA publications such as Matos et al. (2001)). It seems evident that in order to truly understand how mathematics can be used and what the effects thereof are, learners must engage in modelling of complex phenomena themselves (Christiansen, 2001a), and engage in critical reflection thereon (cf. Christiansen, Nielsen, and Skovsmose, 1997). This is a pedagogic challenge, which we have only really begun to address within the past 20 to 30 years (McLone, 1984; cf. Burghes, Huntley, and McDonald, 1982 for early contributions). Substantial progress has been made over recent years, indicating the value of interchanging work with the entire model process with work on specific sub-processes (Blomhøj and Jensen, 2002). One of the real difficulties being that modelling of this nature requires substantial mathematical competencies as well as in-depth understanding of the area being modelled.

In an attempt to obtain the same outcomes with less difficulty, a pedagogic recontextualisation has taken place, in the development of modelling tasks suited for the classroom. Some of these have proven quite powerful in engaging learners in discussions of the role of mathematics in society. ${ }^{3}$ Ole Skovsmose has developed a terminology to talk about the different types of competencies/knowledge/knowing involved in this type of activity:

(a) Mathematical knowledge itself.

(b) Technological knowledge, which in this context is knowledge about how to build and how to use a mathematical model. ...

(c) Reflective knowledge, to be interpreted as a more general conceptual framework, or meta-knowledge, for discussing the nature of models and the criteria used in their construction, applications and evaluations.

(Skovsmose, 1990: 765, see also; 1994)

What remains uncertain is how the various competencies are linked, and to what extent mathematical and/or technological knowledge is a prerequisite for reflective knowledge. We have examples of people criticising the results of mathematical models being applied in society in ways which did not necessarily require substantial insight in the model or the underlying modelling

${ }^{3}$ Cf. the project developed by Henning Bødtkjer, Mikael Skånstrøm, Morten Blomhøj, Helle Alrø and Ole Skovsmose described in chapter 7 of Alrø and Skovsmose (2002), the examples in Skovsmose (1994), and the three cases discussed in Christiansen (1996). Vithal (2003) discusses the implementation of project work with younger learners with the same intentions, but not engaging modelling to the same extent. Though Julie (1991) mentions this aspect as part of the People's Mathematics programme in South Africa, this programme has focused more on curriculum and materials development, and Julie (1993) has indeed criticised the programme for not inviting working with real life problems and for failing to deal with mathematical models that are used to regulate society. It is therefore of less relevance to the particular focus of this paper. As Vithal (2003: 33) suggests: "Perhaps ... people's education ... was not primarily intended and therefore not developed as a substantial educational theory or movement but rather as a political (op)position or programme around which to organise mathematics educators to oppose apartheid education." 
process (Christiansen, 2000). However, the question remains to what extent feeling comfortable with mathematics was an essential enabler nonetheless. We cannot know this with any degree of certainty, but we can be sure that the knowledge of mathematics as well as the technological/modelling competency - as any other tool - effects the relation between the subject and the object, and thus by necessity will influence the reflective knowledge. It is likely to both facilitate and limit the reflective knowledge in various ways. In education as well there are no easy answers.

It is equally certain that the classroom community in which the facilitation of reflective and/or technological knowledge is expected to take place, with its divisions of labour, power relations and rules, will affect the activity. A comparison between three classrooms working with realistic modelling documented that the organisation of the classroom practices and the objectives of the activities determined the extent to which the students engaged with the deeper issues or constructed virtual realities in which to work (Christiansen, 1997; 2001b). However, the absence of reflective knowing was obvious; generally, only when it was put on the agenda by the educators did it surface.

An experiment using project work with South African grade 6 learners confirmed that learners do not easily engage in critical reflections on the roles and effects of using mathematics on the basis of specific cases, even when they are related to projects of their own choice (Vithal, 2003).

Though most of these experiences are from other political, social and cultural contexts, they do illustrate that learners' awareness of the role of mathematics in society is not straight forward to facilitate. Through engagement with authentic problems, classroom practices may still eventually come to frame a reflective practice within which the relation between science, technology, mathematics and society can be addressed in a way which is not possible in the work-related or disciplinary practices. But we do not understand enough about how these practices, with their recontextualised critical mathematics discourse, are developed and sustained, to know how to ensure the vision of the NCS.

\section{Combining epistemological access and social empowerment?}

There were two main reasons to construct an ML school subject for South Africa. The one was to reach the 200,000 learners leaving grade 12 every year without mathematics and the 200,000 additional learners who fail mathematics yearly (see Parker (2004) for an overview of national performance in matric mathematics). The failure of South African learners in international comparison surveys/tests only added fuel to this. Since there are strong indications that adults who are innumerate are seriously disadvantaged in their employment possibilities (Bynner and Parsons, 1997), widespread innumeracy is of both economic and social concern (locally, nationally and globally).

The other reason was to teach learners competencies and knowledge which would be in line with the overall intentions of the National Curriculum. The intentions of the ML NCS (as stated in chapter 1 , common to all the NCSs) are proclaimed for improvement of living conditions, social justice and democracy, in other words directed to overcoming the apartheid legacy.

Mathematics, as a school subject, plays an important role in maintaining the theory/practice hierarchy (cf. Christiansen, 2007). It also serves to maintain a class distinction, which of course is related. It is a well-known sorting tool of learners into those who master the decontextualised, selfreferential discourses, and those who do not. Thus, the introduction of ML as a school subject was in part driven by a vision of a non-esoteric mathematics with real use value, which could still provide reasonable access to further education, etc.

This obviously raises the important question: Is it possible to combine access to existing areas of privilege (epistemological access) and at the same time further social empowerment of learners? Elsewhere (Christiansen, 2000), I have engaged this discussion much further, and it is a wellknown dilemma in mathematics education (Ernest, 1991). But it is of specific relevance to the ML NCS, which in a sense is offered as a local solution to the dilemma.

Just as the Mathematics curriculum (cf. the discussion of the Mathematics curriculum in Naidoo and Parker (2005)), the ML NCS is a political hybrid product. Though it states that "[t]he approach that needs to be adopted in developing Mathematical Literacy is to engage with contexts rather than applying Mathematics already learned to the context" (chapter 3, 'contexts'), it has an obvious focus on mathematical skills and concepts throughout. It is using claims of utility to justify itself, yet its content is distinctly mathematical. Thus, the organising principles of the content remain invisible and inaccessible to the learners. This 
positions them as objects rather than cognising subjects (cf. Dowling, 1998: 46). Thus, the curriculum is likely to contribute to the reproduction of social inequalities rather than promote social justice.

I substantiate this point further in a forthcoming paper (Christiansen, 2007). Here, it suffices to point out that the ML NCS has not given sufficient attention to the complexity of this problem, and therefore also in this respect fails the progressive vision.

\section{Conclusion}

The role of mathematics in society may vary from country to country. The South African ML NCS assumes that mathematics (through the use of mathematical models) does indeed play a role in arguments and the shaping of political society. My first point is to argue that when this happens, transformations of discourses are likely to take place. However, none of this can be assumed known by teachers, in particular since these uses of mathematics often remain hidden to the public. And indeed the examples suggested by the NCS do not engage in any substantial way with these uses of mathematics. This is the second point of the paper. The third is that there is not enough research to give us insights in the connections between mathematical, technological and reflective knowledge/knowing/competencies. To facilitate an understanding and awareness of the role of mathematics in society, it is argued that more drastic measures are required. This raises its own issues, as a discourse belonging to mathematics education and critical applied mathematics must now be recontextualised to the classroom. We know too little about how, if at all, this can be achieved. Finally, I point out that the NCS for ML has not given sufficient attention to the potential tensions between facilitating epistemological access and social empowerment along the lines of the aforementioned awareness and understanding.

Schooling exists as an institution in the intersection between recontextualised disciplines, representing a general epistemic interest, and political life, representing specific epistemic interests. Though disciplines and society influence each other, they are still opaque to each other, partly because of the increased specialisation in the division of labour (cf. Otte, 1994: 130). School can be seen as an attempt to intermediate between these practices, but because of the opacity, this attempt results in the consolidation of schooling as yet another societal institution with distinct practices. $^{4}$

While this restricts the apprenticing into both societal/political/work practices and mathematics, it can also offer an opportunity to reflect on this interplay. It is a worthwhile question to investigate further if this opportunity can be realised, and how. Thus the answer to the title is that this particular ML NCS may, but it is still possible to imagine one that may not.

\section{Acknowledgements}

Thank you to Carol Bertram, Diane Parker, Vaughn John, Morag Peden, and Wayne Hugo for useful input on the first draft of this paper. Thank you to the two reviewers, who forced me to make some of my points clearer and more specific to the South African context.

\section{References}

Alrø, Helle, and Skovsmose, Ole. (2002). Dialogue and Learning in Mathematics Education. Vol. 29, Mathematics Education Library. Dordrecht, the Netherlands: Kluwer Academic Publishers.

Basic Skills Agency. (1997). International Numeracy Survey: A Comparison of the Basic Skills of Adults 16-60 in Seven Countries. London: Basic Skills Agency.

Blomhøj, Morten. (1999). Matematikkens rolle i samfundet og dens betydning for almen matematikundervisning. In M. Blomhøj and L. Øhlenschlæger (Eds.), Rapport fra konferencen "Matematik i samfundet - en begrundelse for matematikundervisning?". Roskilde, Denmark: Center for forskning i matematiklæring.

Blomhøj, Morten, and Jensen, Tomas Højgaard. (2002). Developing mathematical modelling competence: Conceptual clarification and educational planning. In Papers from Centre for Research in Learning Mathematics. Roskilde, Denmark.

Blum, Werner, and Niss, Mogens. (1989). Mathematical problem solving, modelling, applications and links to other subjects: State, trends and issues in mathematics instruction. In Tekster fra IMFUFA. Roskilde, Denmark: Roskilde University Center.

Booß-Bavnbek, Bernhelm, and Pate, Glen. (1989). Information technology and mathematical modelling. The Zentralblatt für Didaktik der

\footnotetext{
${ }^{4}$ One may even conjecture that it is this opacity which 'necessitates' mathematics education as a research discipline, though it is evident that there is no 'optimal' mathematics instruction which can serve all
} the interests put upon it. 
Mathematik/International Reviews on

Mathematics Education 5:167-175.

Bourdieu, Pierre. (1983/2004). The forms of capital. In S. J. Ball (Ed.), The

RoutledgeFalmer Reader in Sociology of

Education. London and New York:

RoutledgeFalmer. Original edition, Richardson, J., Handbook of Theory and Research for the Sociology of Education (1986), Westport, CT: Greenwood, (pp. 241-258). Originally published as 'Okonomisches Kapital, kulturelles Kapital, soziales Kapital,' in Soziale Ungleichheithen (Soziale Welt, Sonderheft 2), edited by Reinhard Kreckel. Goettingen: Otto Schartz \& Co., 1983 (pp. 183-98). Translated by Richard Nice.

Burghes, David N., Huntley, Ian, and McDonald, Ian . (1982). Applying Mathematics: A Course in Mathematical Modelling, Ellis Horwood Series in Mathematics and its Applications. Chichester, UK: Ellis Horwood.

Bynner, J., and Parsons, S. (1997). Does Numeracy Matter? Evidence from the National Child Development Study on the Impact of Poor Numeracy on Adult Life. London: Basic Skills Agency.

Christiansen, Iben Maj. (1996a). Mathematical Modelling in High School: From Idea to Practice. Aalborg, Denmark: Department of Mathematics and Computer Science, Aalborg University.

Christiansen, Iben Maj. (1996b). Realizing critical reflections on mathematical models in the classroom: Dream or realistic idea? In A. Kvamme, T. Kjærgård and $\mathrm{N}$. Lindén. Landås (Eds.), Numeracy, Race, Gender, and Class: Proceedings of the Third International Conference on the Political Dimensions of Mathematics Education Bergen 1995. Norway: Caspar Forlag.

Christiansen, Iben Maj. (1997). When negotiation of meaning is also negotiation of task: Analysis of the communication in an applied mathematics High School course. Educational Studies in Mathematics 34 (1),1-25.

Christiansen, Iben Maj. (2000). Mathematics education and democracy: Some questions. In Proceedings of the 6th National Congress of the Association for Mathematics Education of South Africa: The Beauty of Mathematics. Bloemfontein, South Africa: The Association for Mathematics Education of South Africa.

Christiansen, Iben Maj. (2001a). Critical evaluation of models in relation to the modelling process. In J.P. Matos, W. Blum, K.
Houston and S.P. Carreira (Eds.), Modelling and Mathematics Education, ICTMA 9: Applications in Science and Technology (pp. 391-400). Chichester, England: Horwood Publishing.

Christiansen, Iben Maj. (2001b). The effect of task organization on classroom modelling activities. In J.P. Matos, W. Blum, K. Houston and S.P. Carreira (Eds.), Modelling and Mathematics Education, ICTMA 9: Applications in Science and Technology (pp. 311-319). Chichester, England: Horwood.

Christiansen, Iben Maj. (2007). Mathematical Literacy as a school subject: Mathematical gaze or livelihood gaze? African Journal of Research in Mathematics, Science and Technology Education 11 (1).

Christiansen, Iben Maj, Nielsen, Lene, and Skovsmose, Ole. (1997). Ny mening til begrebet refleksion i matematikundervisningen? In C. Jacobsen (Ed.), Refleksive Lareprocesser (pp. 173-190). Copenhagen, Denmark: Politisk Revy.

Department of Education. (2003). National Curriculum Statement, Grades 10-12 (General): Mathematical Literacy. Pretoria, South Africa: Department of Education.

Dowling, Paul. (1998). The Sociology of Mathematics Education: Mathematical Myths/Pedagogic Texts. Vol. 7, Studies in Mathematics Education Series. London: Falmer Press.

Ernest, Paul. (1991). The Philosophy of Mathematics Education. London: The Falmer Press.

Fasheh, Munir. (1996). The main challenge: ending the occupation of our minds. The main means: building learning environments and recontextualising knowledge. In T. Kjærgård, A. Kvamme and N. Lindén (Eds.), Political Dimensions of Mathematics Education III: Numeracy, Race, Gender and Class (pp.13-26). Bergen, Norway: Caspar Forlag.

Frankenstein, Marylin. (1981). A different third R: Radical Math. Radical Teacher,14-18.

Frankenstein, Marylin. (1990). Relearning Mathematics: A Different Third R - Radical Maths. London: Free Association Books. Jablonka, Eva. (2003). Mathematical literacy. In A.J. Bishop, M.A. Clements, C. Keitel, J. Kilpatrick and F.K.S. Leung (Eds.) Second International Handbook of Mathematics Education (pp. 75-102). Dordrecht, the Netherlands: Kluwer Academic Publishers. 
Julie, Cyril. (1991). People's mathematics, graphic calculators and the development of mathematics culture. In Proceedings of the Fourteenth National Convention on Mathematics and Natural Science Education. South Africa: The Mathematical Association of Southern Africa.

Julie, Cyril. (1993). People's mathematics and the applications of mathematics. In J. de Lange Jzn, C. Keitel, I. Huntley and M. Niss (Eds.), Innovations in Mathematics Education by Modelling and Applications (pp31-40). London: Ellis Horwood.

Jungwirth, Helga. (2003). What is a gendersensitive mathematics classroom? In L. Burton (Ed.), Which Way Social Justice in Mathematics Education? (pp. 3-27). London: Praeger.

Kemp, Peter. (1980). Ekspertise som ideologi. In O. Nathan. København (Ed.). Toenk og Veelg: En Debat om Naturvidenskab, Teknologi og Samfund (pp. 45-59). Denmark: Gyldendal/Nordisk Forlag.

Kibi, Alcott Khaliphile Mzwandile. (1993). For people's power. In C. Julie, D. Angelis and Z. Davis (Eds.), Political Dimensions of Mathematics Education 2: Curriculum Reconstruction for Society in Transformation . Cape Town: Maskew Miller Longman.

Matos, João Philip, Blum, Werner, Houston, Ken, and Carreira, Susana Paula (Eds.). (2001). Modelling and Mathematics Education, ICTMA 9: Applications in Science and Technology, Horwood Publishing Series: Mathematics and Applications. Chichester, England: Horwood Publishing.

McLone, R.R. (1984). Can mathematical modelling be taught? In J.S. Berry, D.N. Burghes, I. Huntley, D.J.G. James and A.O. Moscardini (Eds.), Teaching and Applying Mathematical Modelling (pp. 476-483). Chichester, UK: Horwood.

Mellin-Olsen, Stieg. (1987). The Politics of Mathematics Education. Vol. 4, Mathematics Education Library. Dordrecht, the Netherlands: Kluwer Academic Publishers.

Naidoo, Devika, and Parker, Diane. (2005). The implications of mathematics teachers' identities and official mathematics discourses for democratic access to mathematics. Perspectives in Education 23 (1), 1-15.
Niss, Mogens. (1984). Kritisk matematikundervisning - nødvendig men vanskelig. Unge Pcedagoger (4), 21-29.

Niss, Mogens. (1990). Matematiske modeller, almendannelse og demokrati. In Matematikundervisning og Demokrati: Rapport fra en Konference afholdt 14.-16. juni $1990 i$ Gilleleje, edited by Statens Humanistiske Forskningsråd: Initiativet vedrørende Matematikundervisning. Roskilde, Denmark: IMFUFA, Roskilde University Centre.

Otte, Michael. (1994). Das Formale, das Soziale und das Subjektive: Eine Einführung in die Philosophie und Didaktik der Mathematik. Frankfurt am Main, Germany: Suhrkamp.

Parker, Diane. (2004). Mathematics and mathematics teaching in South Africa: Challenges for the university and the provincial Department of Education. In R. Belfour, T. Buthelezi and C. Mitchell (Eds.), Teacher Development at the Centre of Change (pp.119136). Durban, South Africa: SEMI.

Povey, Hilary. (2003). Teaching and learning mathematics: Can the concept of citizenship be reclaimed for social justice? In L. Burton (Ed.), Which Way Social Justice in Mathematics Education? (pp. 51-64). Westport, Connecticut: Praeger.

Skovsmose, Ole. (1984). Kritik, undervisning og matematik. København, Denmark: Lærerforeningens materialeudvalg.

Skovsmose, Ole. (1990). Reflective knowledge: Its relation to the mathematical modelling process. International Journal of Mathematical Education in Science and Technology 21(5), 765-779.

Skovsmose, Ole. (1994). Towards a Philosophy of Critical Mathematics Education. Vol. 15, Mathematics Education Library. Dordrecht: Kluwer Academic Publishers.

Valero, Paola. (1999). Deliberative mathematics education for social democratization in Latin America. The Zentralblatt für Didaktik der Mathematik/International Reviews on Mathematics Education (1), 20-26.

Vithal, Renuka. (2003). In Search of a Pedagogy of Conflict and Dialogue for Mathematics Education, Mathematics Education Library. Dordrecht: Kluwer Academic Publishers. 